\title{
DR. LUDVIG VIIHELM DAHL.
}

Dr. Ludvig Vilhelm Dahl, who died on the 2nd of November last, was the son of Nils G. A. Dahl, Major of Infantry in the Norwegian army, and was born at Bergen on the 18th October, 1826 . He passed his preliminary examination in 1842, and took the degree of Doctor of Medicine with honours at Christiania in 1851. After filling different hospital appointments and studying some months at Vienna and Paris, Dr. Dahl was admitted as supernumerary to the asylum at Gaustad, where he remained till September, 1861, when he became Medical Officer to the House of Correction in Christiania. From 1864 to 1868 he was employed in the Medical Commission of the Home Department, and in 1871 he became director of the asylum at Rotfold. In 1875 he became director of the Norwegian Medical Department. Dr. Dahl was several times sent by the Government on medical commissions and inquiries to different parts of Burope. In 1864 he visited Switzerland, Italy, and Austria to make an inquiry about cretinism; in 1885 he was sent as delegate to the cholera conference at Rome. At the 400 years' jubilee of the University of Upsala in 1877, the degree of Doctor of Arts was conferred upon him. He also gained a silver medal at the great exhibition held at Paris in 1878, for his graphic illustrations of the statistics of disease and mortality. He was also rewarded with a gold medal from the French Academy of Medicine. Honours and decorations also came to the Norwegian physician from Denmark, Austria, Belgium, Sweden, and Italy. Dr. Dahl is author of a considerable number of treatises on medical subjects. His book, "Bidrag til Kundskab om de Sindssyge i Norge" (Contribution to our Knowledge of Insanity in Norway), Christiania, 1859, found its way into the libraries of many European neurologists. It deals mainly with the causes and distribution of insanity, and especially attracted attention by the careful way in which he traced the descent of hereditary insanity in families dwelling in the quiet valleys of Norway. Some of Dahl's genealogical tables were republished at the end of my work on idiocy and imbecility. - W. W. IRELAND.

\section{MR. WILLIAM MILLARD.}

Mr. William Millard, a man who was well known as a life-long at:d devoted friend to the cause of the idiot, and was highly esteemed among all classes, not only in Colchester, but throughout the Eastern Counties, passed to his rest December 6th, 1890, at his residence, Colchester, after an illness of some con. siderable duration. He was born in London, September 22nd, 1818, and was consequently a little over 72 years of age. His attention to the cause of the idiot commenced as far back as 1847, at which time he was superintendent of a large Sunday School, and had taken charge of three small Sunday evening Ragged Sohools. Having read a letter publikhed in the "Sunday School Teachers' Magazine" on "What can be done for the Education of Idiots ?" Mr. Millard was led to think that as he had been able to gain the confidence and win the attention of rough, ragged, wild youths, he could, perhaps, benefit those lower in the scale of intellect. He made inquiries, and by invitation of $\mathrm{Dr}$. Andrew Reed, the founder of the London Orphan Asylum and other charitable institations (who was then working in the canse of the idiot), he joined his Institutory Committee, and a public meeting was held, which resulted in the fonnding of the Asylum for Idiots at Earlswood, and Mr. Millard commenced his 37 years' official service in the cause. In six months after the opening of Earlswood it was found necessary to open a branch asylum, and Sir Morton Peto offered the use of Essex Hall, at Colchester, at a nominal rent, and Mr. Millard brought down the first batch of patients on January 8th, 1850, while in 
July of the same year he was sent down to take charge of the establishment. The following year he commenced a canvass of the Eastern Connties in order to render Essex Hall an independent institution. Mr. Millard's great work in connection with Earlswood is matter of history, and the part he took subse. quently in 1858 in establishing the present Asylum at Colchester is well known and much appreciated. Ho resigned his connection with Earlswood on December 25th, 1858, and standing shoulder to shonlder with Dr. Reed, at once set to work to start the Asylum at Colchester as an independent Asylum. In 1859 the institutory meeting was held, and deceased was appointed superintendent and secretary. As time went on he had the happiness to see the prospeots for which he laboured so zealonsly and conscientiously, prosper beyond his most sanguine expectations, extension of the premises being rendered necessary more than once during his management, and the freehold of Essex Hall being purchased from Sir Morton Peto. In 1874 Mr. Millard resigned the secretaryship, feeling unable fully to discharge its duties as well as those of superinten. dent, and he generously offered to give ap a fourth of his salary, but this was declined by the Board of Directurs, who appointed Mr J. J. C. Turner (the present saperintendent) as secretary. In 1884, Mr. Millard, on account of failing health, also resigned the superintendence, and in recognition of his past valuable services his name was placed apon the Board and House Committee, and he continued to take a deep interest in the welfare of the institation, thongh for the past 18 months he bas been prevented by illness from visiting it. We believe that besides his work in connection with Earlswood and Fssex Hall, he assisted in founding several similar asylums in other parts of the conntry, including the Scottish Asylum, the Western Counties', the Royal Albert Asylum for the Northern Counties, the Knowle Asylum for the Midlands, the Irish Asylnm, etc. Mr. Millard wrote a "History of Essex Hall" in 1864, by request of Sir Morton Peto, in order to awaken interest in the cause in the Northern Counties, and in 1866, in conjunction with Dr. Duncan, the first Medical Officer of Essex Hall, he brought out a manual on "The Training and Classification of Idiots and Imbeciles." In 1875, too, he helped Sir Chas. Trevelyan to organize a special Committee in connection with the Charity Organization Bociety, to promote legislation with reference to idiots and harmless lnnatics, and in many other ways he assisted the idiots' cause, of which he was a frequent adrocate at pablic meetings.

Mr. Millard, it is not too much to say, was greatly beloved by the offioials and all with whom he was brought into contact during his active connection with Fssex Hall, and the news of his death, though not nnexpected, has been received with profound grief.-Essex Paper.

\section{DR. G. D. SYMES.}

We regret to have to record the nnexpected death, on March 7th, of Dr. George Dickenson Symes, Assistant Medical Officer at the Lancashire Connty Arylum, Rainhill, aged 30. He was the son of Dr. J. Gustavus Bymes, Sonth. field, Weymouth, late Medical Superintendent Dorset Connty Asylnm.

$A$ severe cold and sore throat developed into a quinsy, the abscess bursting in the usual way, but instead of convalescing he got general septio infection with double pleuro-pnenmonia, which carried him off with extraordinary rapidity. He was always rather delicate, and seemed to have no stamina to withstand an acnte illness. His death is lamented by all who knew him, and has cast a gloom over the asylum, where he was greatly esteemed as a good officer, courteous to all, and loyal to his chief.

He was formerly Clinical Assistant at Bethlem Hospital, where he earned the respect and affection of both the patients and the medical stafi.

We desire to expreas our deep sympathy with the family in their berearement. XXXVII. 